\title{
SURVEY, STRATIGRAPHY OF THE ELEVATIONS, 3D MODELLING FOR THE KNOWLEDGE AND CONSERVATION OF ARCHAEOLOGICAL PARKS: THE CASTLE OF AVELLA
}

\author{
M. D’Aprile, M. Piscitelli*
}

\begin{abstract}
Department of Architecture and Industriale design, Università degli Studi della Campania Luigi Vanvitelli, Italy,
\end{abstract} (marina.daprile@unicampania.it, manuela.piscitelli@unicampania.it)

KEY WORDS: archaeology of architecture, medieval fortifications, front orthophotos, image-based survey, photogrammetry.

\begin{abstract}
:
The site of Avella is a precious example of ruined medieval fortification with territorial and landscape values. The width and vulnerability of its masonry remnants require a systematic survey and physical investigation, necessary to any preservation and enhancement strategy planning, so far, not yet extended to the fronts of the fortress and the two walled lines. The understanding of the process, scientifically based, which over time has led the buildings to the present state of fragmentation has the same need. Obtain with expedited methods and customary instruments a photogrammetrically controlled survey, the stratigraphic study of the castle elevations and the processing of a photo-based 3D model is therefore the aim of the paper. Carried out on an interdisciplinary basis, it comes from the extension of the outcomes of a didactic workshop in master's degree courses in Architectural Survey and Restoration Design, held in 2018. The surveying procedure with the drone proved to be the most suitable, also for the possibility of an expeditious and cheaper measurement phase compared to other surveying methods. The results comprise the fortress georeferenced ortho-photomosaic and its photo-based 3D model, then exported both as a point cloud and a 3D mesh. The workshop also implemented topography and terrestrial photogrammetry procedures, such as to be compared with the previous one.
\end{abstract}

\section{INTRODUCTION}

The fortified site of Avella (AV) is a key paradigm of ruined built heritage with relevant landscape and territorial features. (Fig. 1). The width and the fragility of remnants and the necessary accuracy of building survey outcomes, being the basic tool to any preservation design, are not always able to combine cost-efficiency and appropriate scientific approach. Precise building survey and documentation procedures are, indeed, main requisites to any heritage enhancing practice too, especially to extending a more comprehensive and understandable knowledge of ruined artefacts and their historical development phases to a wider user community, thus suggesting how buildings have reached today's fragmentated states of condition.

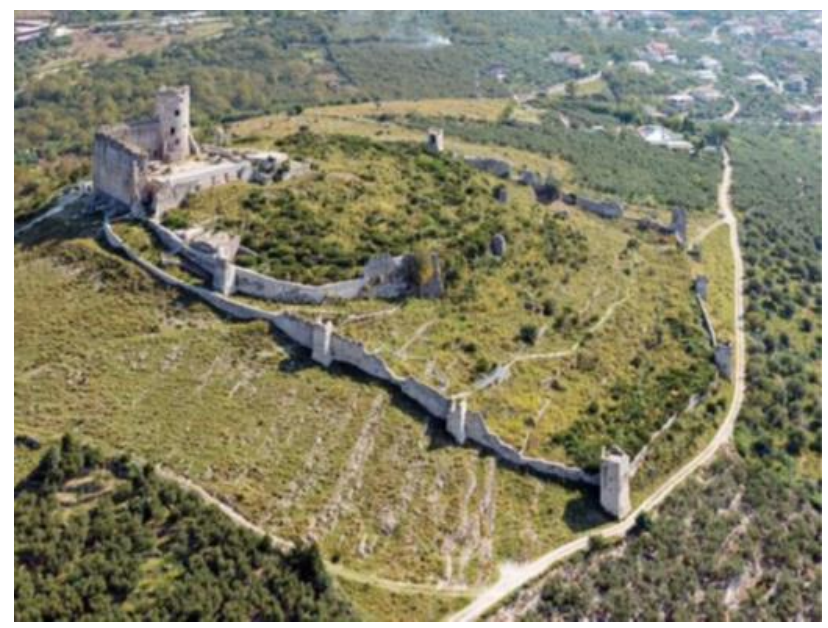

Figure 1: View of the castle of Avella.
To perform photogrammetric survey expeditiously and userfriendly constitutes an important goal from a master-level formative point of view. Therefore, to combine architectural surveying and restoration design teaching approaches, from May to June 2018 the authors of this paper, which is based on that event, with the ANALIST Group's consultancy for 3D modelling software, organised and managed a scientific-didactic workshop at the Department of Architecture and Industrial Design of the University of Campania "Luigi Vanvitelli" (Survey, knowledge and enhancement of archaeological parks: the fortified site of Avella). Combining ex-cathedra lectures to on-site activities concerning architectural and stratigraphic surveying methods, they experienced both traditional and updating means of direct and indirect architectural survey, to reach the more appropriate building representation able to interpret and visualise the case "archaeological knowledge". Through a 3D photo-based model of the fortified site of Avella, obtained thanks to Pix4D Mapper and Analist Cloud software, the orthophotos of some fronts of the outer fortified wall have been processed, such as samples on which to perform the stratigraphy-based methodology applied to upstanding structures, thus investigating relevant historic development phases. Thanks to the consultancy of arch. Giuseppe Mollo, moreover, the photo-based survey outcomes were also compared to more traditional methods, such as to ascertain which one can combine cost-efficiency, accuracy and expedition of implementation in widely ruined and vast heritage building.

\section{RELATED WORKS}

Survey represents a key tool to built heritage preserving (Brogiolo, 1988). Its role in building conservation design has

\footnotetext{
${ }^{*}$ Even if the study was coordinatively directed and managed by both the authors, where no differently indicated, the writing of this paper was divided as follows: M. D'Aprile wrote the paragraphs 1 and 3, while M. Piscitelli the paragraph 4.
} 
been, indeed, underlined since the very beginning of the restoration discipline, as the main tool to investigate and interpret material features of artefacts, as well as to perform any design intents. In this scenario, it is useless to highlight how much 3D digital modelling techniques do contribute to building interpretation and archaeological understanding (Parenti, 2009). When current state of condition allows it, this last is especially central on a stratigraphy-based standpoint, thus basically contributing to ascertain historic building development phases (Harris, 2003). It's well known, indeed, that since the late 1970's thanks to some Tizianno Mannoni's pioneer studies, the archaeological stratigraphic theory has been extended to architectural heritage investigation and understanding, substantially carrying the criteria used to read the site-formation process to that of architectural development phases (Gallina, 2012). In this perspective, it's undoubtable 3D visualization of artefact photogrammetric models constitutes a key tool to ascertain temporal relationships (chronologies) by surveying and interpreting physical links among building portions and components, basing on a "stone-by-stone" reading path.

This approach has clear consequences on a preservation standpoint, as well. In physical contexts widely characterised by a comprehensive state of degradation and ruin, if the width of remnants plays a key role too, accuracy, cost-efficiency and easy-to-use approach of relevant surveying methodologies are, therefore, of basic importance and need to be appropriately chosen.

Several recent works have analyzed the possibilities of survey offered by low cost technologies to obtain data expeditiously. Recent computer developments in the field of photogrammetry have increased its performance and automated many restitution procedures, bringing it back as a fundamental technique for archaeological and architectural survey. (Luhmann et al, 2006; Remondino, 2011). Survey methods from unmanned aerial vehicles, in particular drones, are now being consolidated and, due to their handling and transportability, are very useful, especially in the case of structures over large areas and with difficult access. (El-Hakim et al, 2007). Drone-based surveying with image-based technologies enables fairly accurate threedimensional models to be obtained, which, eventually integrated with other surveying techniques, have been shown to lead to satisfactory results. (Luhmann et al, 2014; Remondino \& El-Hakim, 2006; Tumeliene et al, 2017).

\section{THE CASE-STUDY}

The castrum of Avella (AV) is located close to the river Clanio, at $320 \mathrm{~m}$ a.s.l., at the top of a hill, part of the Apennines of Campania's region surrounding Naples's plane from the East. This position had an important strategic role to control from above the surroundings and the natural path that, through Monteforte Irpino's pass, linked the Campania plane to the river Sabato's valley up to reach Apulia region and the Adriatic. Today, the site can be reached coming from via dei Normanni, a little rural vehicle road.

Nevertheless, it is among the main medieval fortified sites in Campania, only from the late past century some archaeological investigation and excavation were there systematically carried out, due to decision to made of it an archaeological park. The archaeological analyses so far have only involved the fortress, as to survey it and determine a first stratigraphy-based periodisation of its phases of occupation. At the top of the hill is located the fortress, dominated by a massive cylindrical tower on a cut-off conical base, welded to the ruined structures of a great donjon (Fig. 4). (Coppola, 2015).

Two fortified boundary walls erected at different height surround the hill flanks, joining themselves at the fortress base along the northern side (Fig. 3).

The interior wall, dated to the Langobard era (Peduto, 1984), follows an elliptical layout, comprising an area of about 10000 square metre within. It preservers ten semi-towers, largely ruined: five have a cut-off conical section while four are of cutoff pyramidal shape. The last one was then incorporated at the base of the donjon northern corner. The outer fortified wall erected during the Norman era $\left(11^{\text {th }}-12^{\text {th }}\right.$ century) following a polygonal layout had the main door at the South-East and surrounds an 21000 square metre area. It presents eight quadrangular towers and one, located at the south-western corner, with a pentagonal layout. Towards the South, between the two walled lines, are still recognisable many masonry remnants clearly belonged to housing structures among which, just against the inner fortified wall, is located a big rectangular tank.

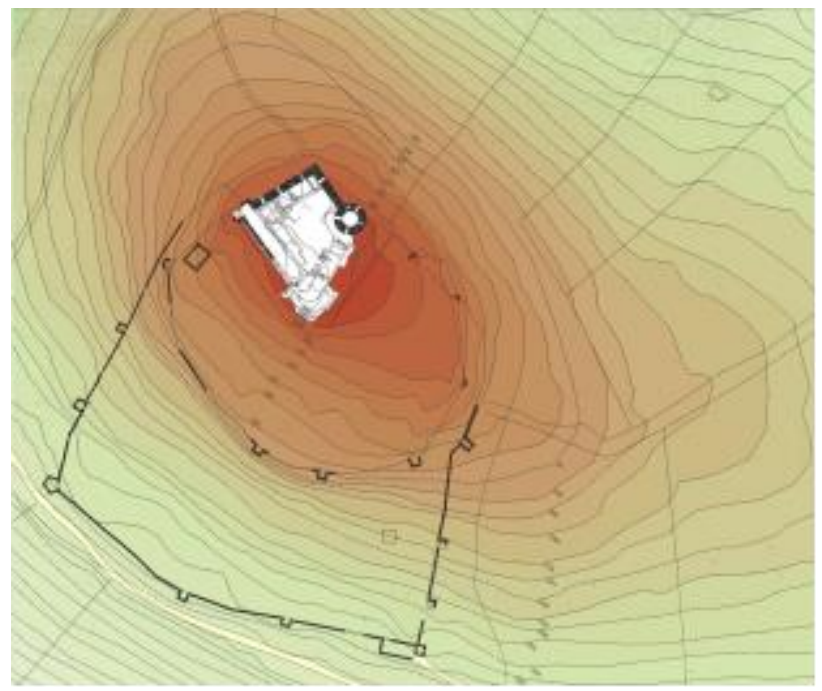

Figure 2: The map of the site (PIT, 2003).

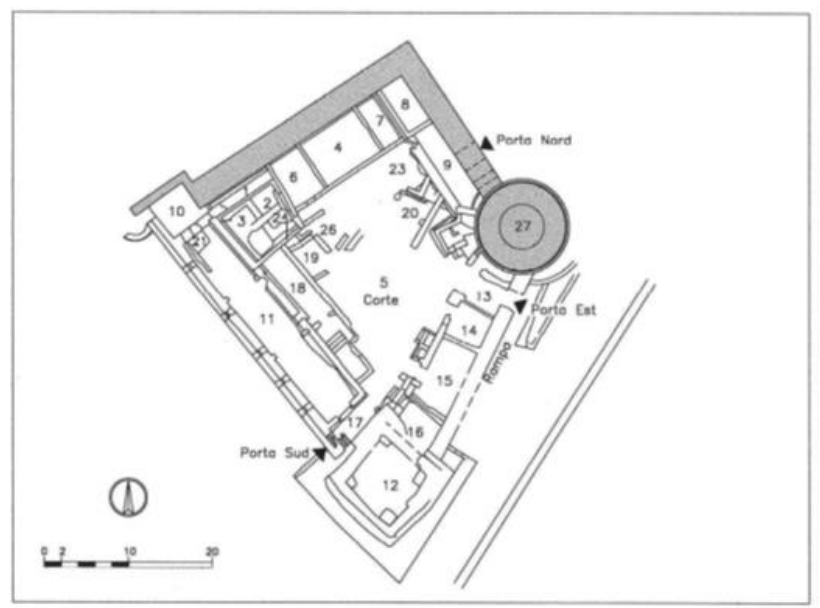

Figure 3: The archaeological map of the fortress. (Cinquantaquattro et al., 2003).

\subsection{Historic documentation and building development phases}

Even if it's possible the cited hill was already occupied during the Ancient time, the prior urban development phases of the ancient town of Abella, located where today is the historical centre of Avella, along an important route linking the Greek coastal towns to Irpinia's region, date back to the late $8^{\text {th }}$ and the early $9^{\text {th }}$ century BC. (Fig. 4). 


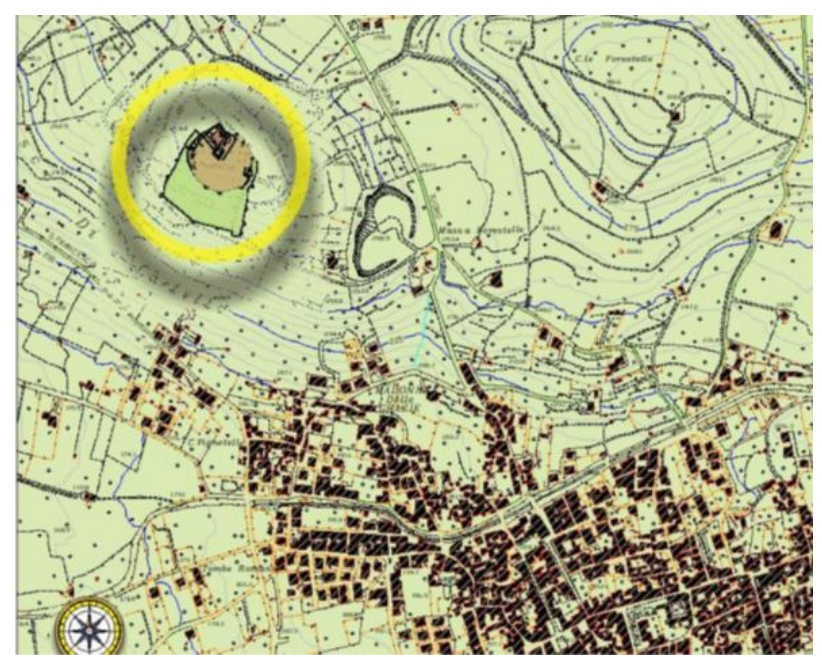

Figure 4: The map of Avella town and the fortified site. Detail.

The main period of this ancient walled town should be dated to a time ranging from the late $2^{\text {nd }}$ century $\mathrm{BC}$ to the $1^{\text {st }}$ century AC (Cinquantaquattro et al., 2003). Many archaeological campaigns have been carried out on the site since the late $20^{\text {th }}$ century, bringing to light precious testimonies of varied chronologies, among which there are the famous amphitheatre, erected by tuff masonry layered in opus reticulatum, the cryptoporticus and different sepulchres founded in the two necropolis areas located outside the urban wall, at the East and West (Cinquantaquattro et al., 2005). Abella's progressive evacuation started during the $4^{\text {th }}$ century. At least for one more century, the ancient town slowly shrank as several small independent housing clusters, then definitively abandoned due to different barbarian raids and the volcanic events of the late $5^{\text {th }}$ and the early $6^{\text {th }}$ century. (Cinquantaquattro et al., 2003). The ancient Abella's slow disintegration at last corresponded to the occupation of a new safer settlement, progressively erected up on the close hill, due to the more strategical position. Basing on the current literary review, the very first attendance of Avella's village should be referred to the $5^{\text {th }}$ or the $4^{\text {th }}$ century BC.

The archaeological excavations at the medieval fortified site of Avella were carried out during three stages by the Archaeological Heritage Local Authority (Superintendence) of Salerno's, Avellino's and Benevento's provinces, in 1987, 2000-2001 and 2005. During the first one, while the outer walled line was restoring, several investigating tests were carried out systematically (Iannelli, 1989). In 2000-2001 the fortress donjon was then surveyed and analysed (Cinquantaquattro et al., 2003), while in 2005 some archaeological excavations involved both the fortress and the Langobard fortified wall (Cinquantaquattro et al., 2005).

The first fortified settlement should date to the $7^{\text {th }}$ century, when the town of Avella belonged to the Langobard Dukedom of Benevento. As stated in 849 by the Divisio Ducatis Beneventani, Avella was then assigned to the Langobard Principality of Salerno, so definitively increasing its strategic role, as being it at the borders among the Langobard Principality of Benevento, the Byzantine Dukedom of Naples and the Langobard Dukedom of Capua. Its presence did must guarantee the control of the Byzantine possessions and the ancient path to Avellino and Benevento. The prior historical testimonies, as referred by Erchemperto, dated back to the second half of the $9^{\text {th }}$ century, regarding some attacks, as the Byzantine one in 887 which brought to the fall of the Langobard gastaldo Landolfo (Erchemperto, 1995). Another robbery, this time performed by Ungari in 937, is documented in the Chronica monasterii Casinensis. Among the current masonry structures positioned up on the hill, the inner surrounding wall should be dated to this period of great insecurity. This wall was originally armed with towers of different layout. Basing on the outcomes of the cited archaeological excavations, it can be assumed that at that time a fortress was already erected at the top of the hill. A portion of this first castle, founded at the South of the north-western wall of the donjon, should correspond to the remains of a wall made by large tuff cut-stones, dated from the end of the $10^{\text {th }}$ to the beginning of the $11^{\text {th }}$ century. At the same historic building phase belong a close cistern and a room placed against that wall (Peduto, 1984).

Thanks to the Norman conquest the Langobard states in South Italy came to an end. By the Catalogus Baronum it can be stated Rainaldo Mosca was then the owner of the fief of Avella (Catalogus baronum, 1972). The Mosca's maintained this possession from the Norman to the Swabian period (Coppola and Muollo, 1994). Thanks to the outcomes of the 1987's archaeological excavations it can be stated that the outer walled perimeter dates to the $11^{\text {th }}-12^{\text {th }}$ century, while different masonry reinstating works were carried out on it during the $13^{\text {th }}$ and the $15^{\text {th }}$ century. (Fig. 5-6). The investigations in the early $21^{\text {st }}$ century determined the donjon chronology, dating it from the half of the $12^{\text {th }}$ to the $13^{\text {th }}$ century, while the fortress was referred to a period ranging from the $10^{\text {th }}$ to the $17^{\text {th }}$ century. During the Angevin reign, more probably in the $14^{\text {th }}$ century, the massive cylindrical tower on a light sloped base was joined to the prior donjon, such as to protect as a flanking fire disposal the whole structure. As stated by the Registers of the Angevin Chancellor's Office, during the $13^{\text {th }}$ century Avella already housed a medium-size community of about one hundred families, which cared the castle as a part of a wider territorial defensive system, as well as the two walled lines.

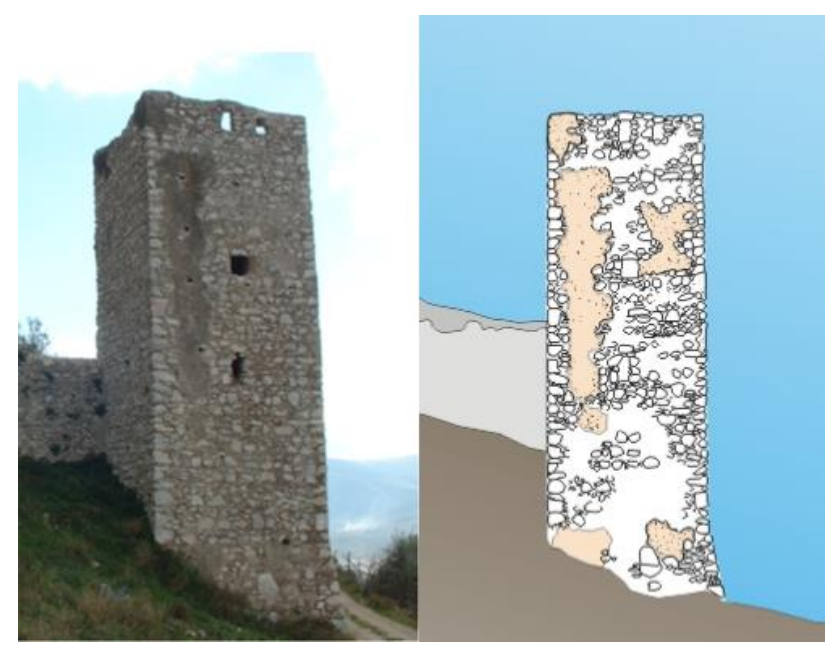

Figure 5-6: The south-western corner tower of the outer walled line front and its building techniques (PIT, 2003).

The site development went on up to the beginning of the $17^{\text {th }}$ century, when the fortified village was definitively abandoned, preferring to return to the prior site of the ancient town of Abella, where the modern settlement was then reconstructed. Indeed, Avella's castle decadence had already started during Orsini's possession of the fief (1432-1529), maybe also because of severe damages caused by the earthquakes in 1456 and 1466 . A 1529's Spanish document from the Historical Sicamancas Archive describes the site as a "forteleza con una terra iunta disabitata; sobre un monte sta el castello, mal tratado dunque 
antiguamente era bello y grande" (Cordella, 1997). In 1534, when the fief passed to the Colonna's, its degradation further increased due to the preference for the new position within the ancient Abella perimeter, where the owners constructed their palace, too. After that the Spinelli's became the new owners (Coppola \& Muollo, 1996). Pietro restored a fundamentis the fortress in 1553 , inserting a pronged rampart at its southern corner, today preserved only at the base. This lanceolate structure might have substituted a prior corner tower. What the archaeological excavations can prove so far is that this building caused the obliteration of a door, linking the donjon to the area within the inner walled perimeter.

An important appraisal of the site dated to 1603 . It describes a castle with a citadel and a palace on the top in which there were eight rooms per storey and other comforts, and where there was a massive tower. The citadel with its twelve turrets surrounded a village already uninhabited and widely ruined, in which there were a parish and a very big cistern. The castle, the appraisal tells, housed a castellan and some prisoners. It had very high walls, which prove that their building had required much ability and great costs (Coppola \& Muollo, 1994). Few years later, the site was certainly abandoned, as the founding of a volcanic ash deposit datable to 1631's Vesuvius eruption clearly demonstrates (Cinquantaquattro et al., 2003).

\section{METHODOLOGY}

The use of image-based survey methods, i.e. based on the acquisition of images from which three-dimensional models of the surveyed area can be derived (Remondino \& El-Hakim, 2006), in recent years has led to consolidated and effective procedures for the surveying of large structures and archaeological sites. These techniques utilize the light present in the environment to acquire photographic images, which are then processed to obtain 3D information about the area.

In addition to the traditional terrestrial and aerial photogrammetry, the use of UAVs (unmanned aerial vehicles) has recently been added. In particular, drones have proved to be very useful for the acquisition of nadiral or oblique images with low costs and good metric accuracy. The transportability, usability, and capacity to reach even inaccessible areas has determined a great success in the field of architectural and archaeological survey. The choice of the most appropriate survey technique depends on many factors, such as the purpose of the survey, the budget, the characteristics of the site, the accessibility of the same, the level of detail required. (Remondino, 2011).

In the case of very large sites, such as the one presented here, several integrated survey techniques are often used to obtain a total overview of the characteristics of the object of study. Such a circumstance often occurs in the case of fortified structures as castles, which due to their defensive nature exploit elements of natural protection that often make it difficult to access and acquire data. In addition, there are no elements, such as welldefined geometries, modularity, symmetries, which in other types of structure facilitate the interpretation of the form and consequently the project of the survey. (El-Hakim et al., 2007).

\subsection{Image-based survey of the Avella castle}

In the specific case of the castle of Avella, the survey presented difficulties due to the state of conservation classifiable as ruins, the considerable size (the external walls enclose an area of about 21,000 square meters), the orography of the ground on a steep slope on which the two walls develop, the presence of a dense vegetation that makes inaccessible some portions of the external walls.

These conditions led to excluding certain surveying techniques, such as the terrestrial laser scanner, whose application would have been difficult due to the orographic conditions, and extremely expensive since a considerable number of surveying stations had to be positioned, for which it was still difficult to find a suitable location in some areas. The survey was carried out using mainly images taken from a drone, and subsequently integrating the data acquired through topographic survey and terrestrial photogrammetry. (Luhmann et al, 2006).

For the conditions described above, the drone surveying approach has proven to be the most appropriate for the specific case study, allowing for more expeditious and economical surveying than other surveying methodologies. In fact, it has made it possible to obtain a three-dimensional model of the surveyed area, visualized in the form of a cloud of points or a 3D mesh, including the orography of the hill on which the castle stands, which is essential for understanding the structure. The technique is based on the acquisition of a set of digital frames of the object, taken in sequence and with an adequate overlap. In the case of objects with not well defined geometric edges, to which it is possible to attribute the structure in question being largely reduced to the state of ruin, the automatic procedure of image matching is preferable because it allows to extract a large number of matches between the different images. The fusion of the photographic images through the corresponding points thus identified allows to obtain a threedimensional model in the form of a point cloud, comparable to a model obtained through surveying techniques with active optical sensors such as laser scanners. (Pierrot-Deseilligny et al, 2011).

The accuracy of the model depends on the resolution of the images taken and the overlapping of them, so using a highquality camera and a fixed focus lens you can achieve an appreciable level of precision. The accuracy of the spatial positioning of the vertices of the three-dimensional mesh depends on the focal length of the camera, the resolution of the image, the distance of the device from the subject to be photographed. (Tumeliene et al, 2017).

In order to shoot under optimal conditions, homogeneous and constant lighting is necessary, avoiding overexposed areas and other areas covered by the shadows. A further advantage of these acquisitions is the possibility to capture simultaneously both the geometric information and those related to the textures and colours necessary to create a photorealistic threedimensional model. The activity was performed with the assistance of the company Analist group, which provided technical support for the flight and then for data processing. The survey activity consisted in the acquisition of the data set necessary for the topographic survey on a photographic basis and for the digital photogrammetry from a drone DJI Phantom 4. (Fig. 7).

The flight was planned through a sequence of linear paths side by side on the identified area. The flight technique used is the so-called low altitude panoramic, which compared to the speed of the vehicle requires frequent shots and consequently reduced exposure times. The frequency of the shots was programmed every 4 seconds to obtain, at the planned flight speed, an overlap between the frames of about $80 \%$. This overlap makes it possible to identify points in common to several images, to be used as concatenation points to obtain the orthophotos and as support points for the transformation of the images into a threedimensional model. The software used for image acquisition is Pix4DCapture. 


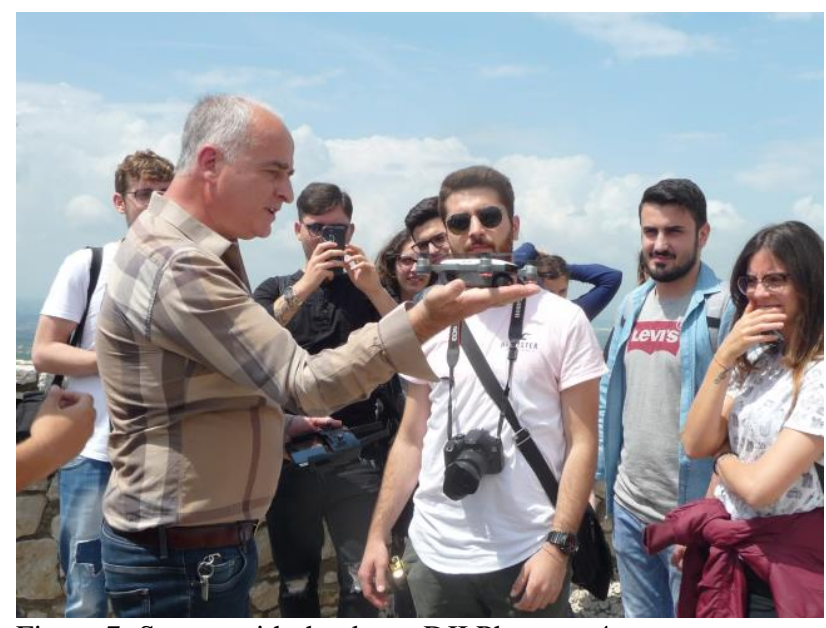

Figure 7: Survey with the drone DJI Phantom 4.

\subsection{The image matching}

The operations of concatenation of the images are automatized by the appropriate software during the phase of restitution of the acquired data. During the image merging process, the software also eliminates the perspective deformation present in the images due to the low altitude where the images were taken. Moreover, the drone's equipment with an internal GPS allows to detect the spatial position and the position of the camera at the moment of the images capture, so that the orthophotos subsequently processed are georeferenced. (Luhmann et al, 2014). Alternatively, images can be georeferenced through ground control points with known geodetic coordinates.

The image matching was made with the Pix4Dmapper software. The application imports captured image swipes, automatically connects common points and reduces errors in the drone's internal GPS. The tolerance, estimated at a few centimetres, can be considered acceptable considering the large size of the area in question, the advantages in terms of time and budget of this technique of surveying and the scope of the survey itself. Orthophotos and 3D models can thus be obtained. (Fig. 8-9). An orthoimage is an orthographic projection where a Digital Terrain Model is mapped using oriented photos.

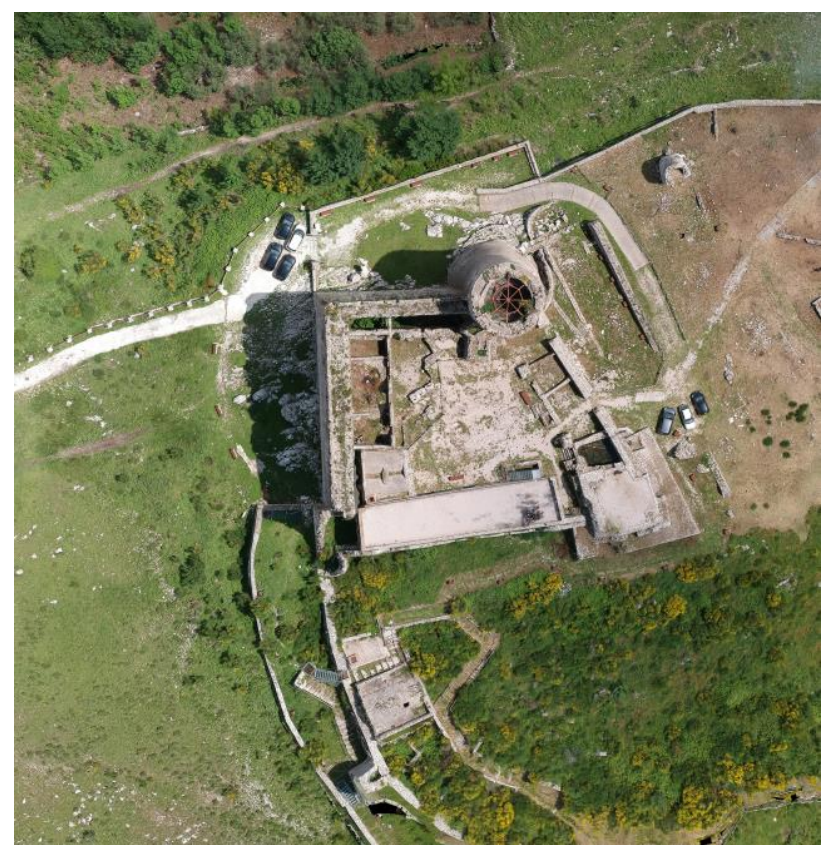

Figure 8: Ortho-photomosaic of the donjon.

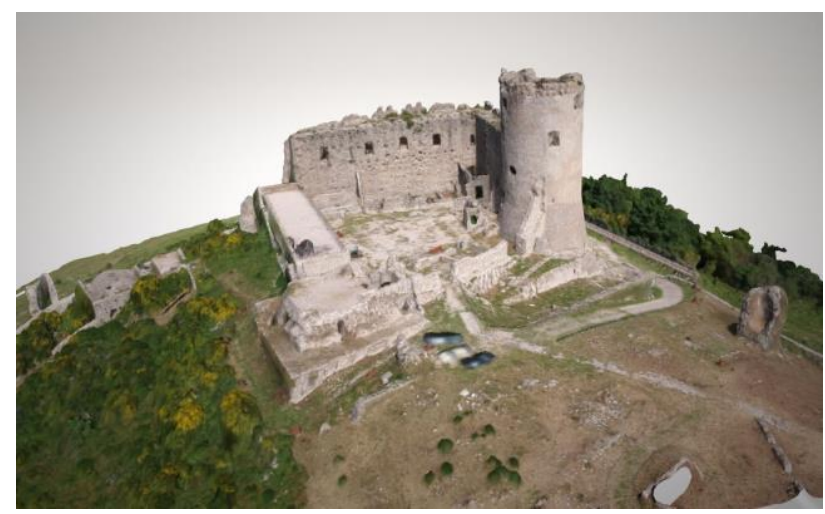

Figure 9: 3D mesh of the donjon.

From the georeferenced ortho-photomosaic obtained for the entire area, it was possible to extract level curves through the Analist Cloud software, which generates quoted plans, profiles and sections from point clouds.

The three-dimensional model can be exported as a point cloud or 3D mesh, and can also be used for 3D printing, to create physical models in scale of the surveyed area. Further uses can be photorealistic animations of the area. The same results can be obtained processing the images through other modelling software from images, such as Context capture, Photoscan, Autodesk ReCap. (Yastikli and Özerdema, 2017).

\subsection{Integration with other survey techniques}

To verify the accuracy of the data acquired with the drone, the survey activity was integrated with the use of topography and terrestrial photogrammetry. These activities were also carried out for educational purposes, to compare times, methods and results. The topographic survey concerned in particular the southern area of the external walls, where the presence of a road that runs parallel to a segment of the walls has allowed an easier positioning of the stations. The comparison between the data obtained from the drones and the topographic survey confirmed a reasonable accuracy in the measurements derived from the images, which undoubtedly justifies their use considering the significant saving of time in the acquisition and the possibility of reaching the areas of the walls where it is not possible to place the stations due to the high slope of the ground, particularly in the east and west sides.

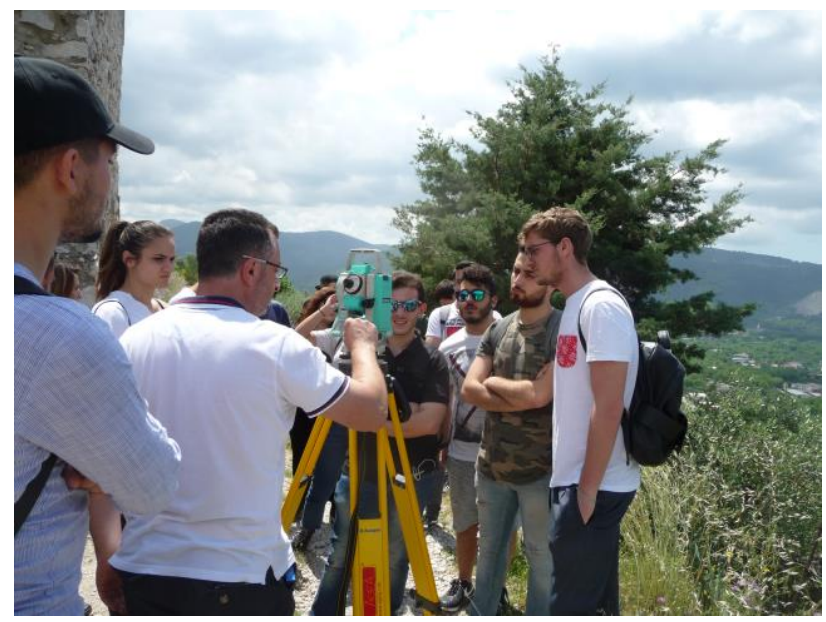

Figure 10: topographic survey.

Further integrations, again for educational purposes and to compare the different techniques of data acquisition, have been 
developed through terrestrial photogrammetry, on the same area covered by the topographic survey. (Fig. 11). The shots were taken using the same technique as the overlapping images used for the drone shots. The data obtained were used for the production of ortho-photomosaic of the walls, and perform the stratigraphic study of the elevations.

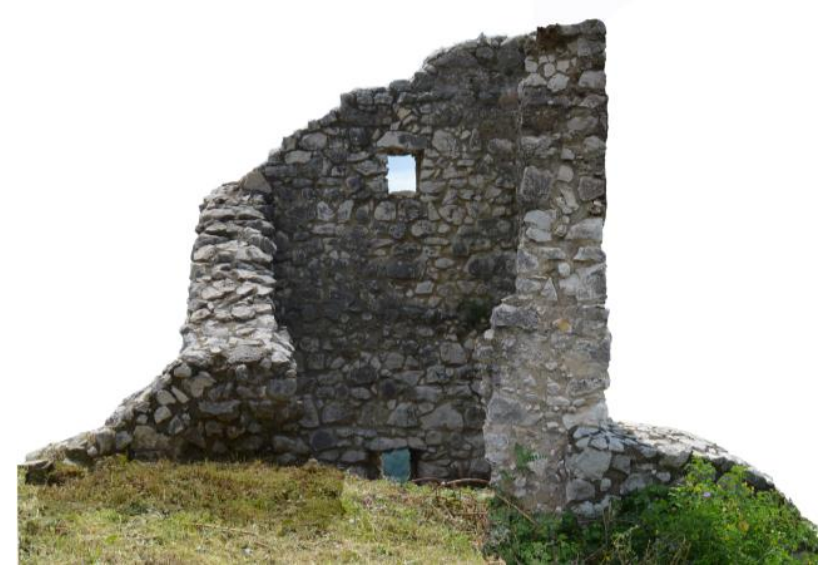

Figure 11: orthophoto of a tower.

\subsection{Outcomes}

The survey has several objectives. First of all, the documentation of the state of fact, whose no complete geometric survey was available to date. The interpretation of the geometries can help to determine, together with the documentary sources and the comparison with other similar typologies, the original shape of the structures and the subsequent modifications. The study is part of the renovation of the castle carried out by the municipality of Avella, which has made some areas of the castle available and created paths for access and visit.

Further outcomes, still under development, concern more specifically the tourist enjoyment of the castle. Also, in this case they are part of the enhancement of the area already in action, through modalities of fruition of augmented reality.
Unlike Virtual Reality that tends to replace the real world with a virtual environment, Augmented Reality integrates the real world with information and virtual objects. With this technique it will be possible to visualize the construction phases and the shape of the castle in different eras, in a continuous comparison with the current state of simple understanding even for a nonspecialist public.

\section{CONCLUSIONS}

The processing of orthophoto-mosaics of the fronts of the outer walled line and some of its towers facilitates the investigation and understanding of building techniques and stratigraphic features (Fig. 12-13). There can be recognised the prior masonry portions made essentially with medium and small limestone irregular blocks layered in coursed-rubble faces (at every $27-33 \mathrm{~cm}$ ), and some cut-and-paste limestone rubble walls of similar coursed layering, but of different chronology (13th-15th C.), height of the courses $(40-50 \mathrm{~cm})$ and size of the blocks (medium). The contemporary reinstated wall facades, instead, use larger limestone irregular blocks coursed layered, even mixed with rare bricks on horizontal axis.

The outcomes demonstrate the effectiveness of image-based surveying techniques, especially by drone, carried on structures of considerable size, characterized by difficulty of accessibility of some areas and lack of well-defined geometric characters. The low cost of the instrumentation, the excellent manageability and transportability, the very short acquisition times make it a very interesting expedite technique. The comparison with other surveying techniques also shows a good result for the case study here examined.

\section{ACKNOWLEDGEMENTS}

The authors would like to acknowledge engineer Antonio Iannuzzi (ANALIST Group) for providing the software and the digital processing consultancy, $\mathrm{PhD}$ architect Giuseppe Mollo for his participation and help to the cited Workshop and the major of Avella's Municipality lawyer Domenico Biancardi for the great availability demonstrated.

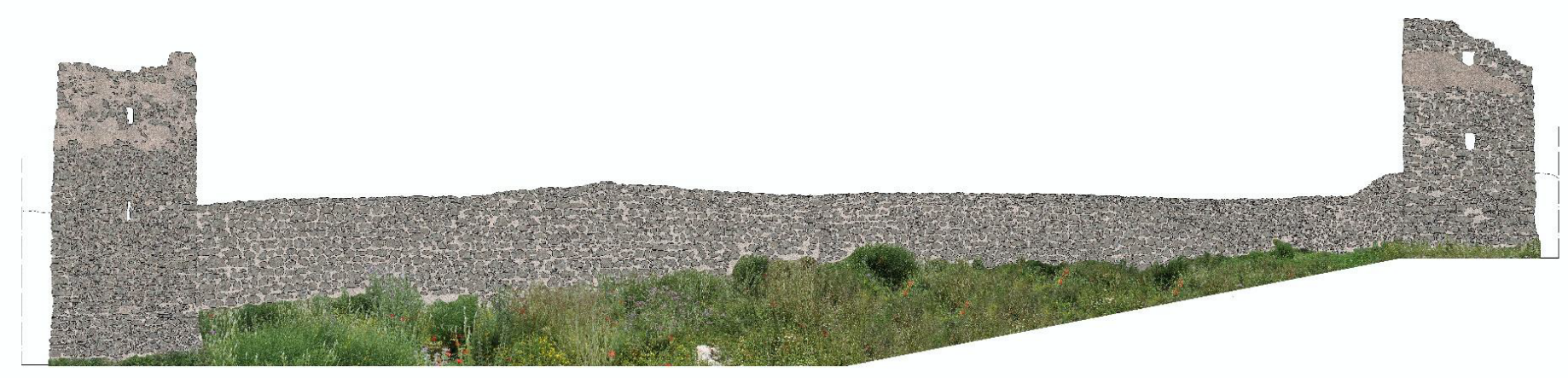

Figure 12: orthophoto-mosaics of the south wall. 


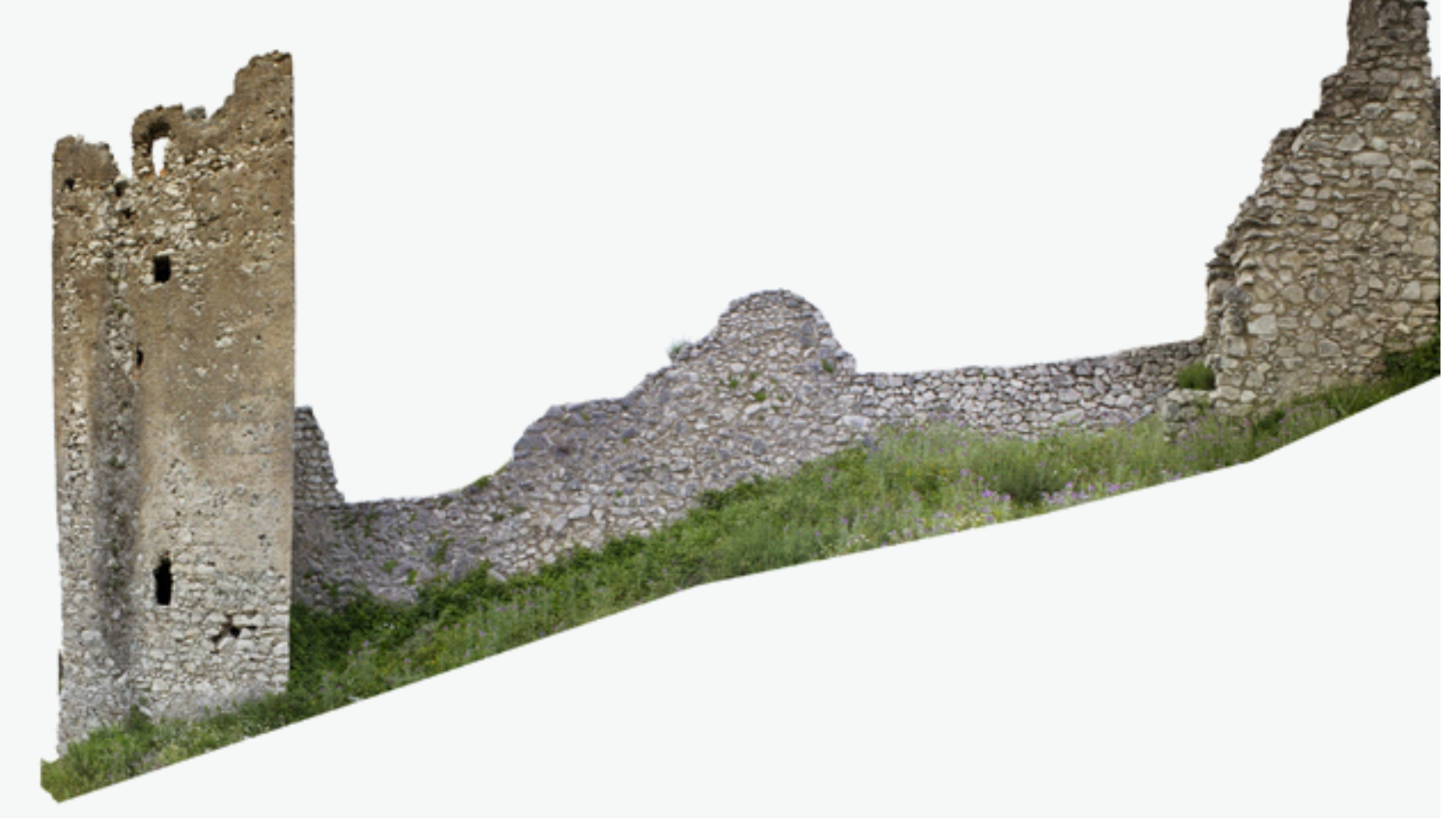

Figure 13: orthophoto-mosaics of the east wall.

\section{REFERENCES}

Brogiolo, G. P., 1988. Archeologia dell'edilizia storica. Documenti e metodi. Como.

Catalogus Baronum 1972. Jamison E. (ed), Catalogus Baronum, Roma 1972.

Cinquantaquattro et al. 2003. Cinquantaquattro, T., Camardo, D., Basile, B. Il castello di Avella (AV): le indagini archeologiche sulla rocca. In: Atti III Congresso nazionale di Archeologia Medievale, Firenze, pp. 355-361.

Cinquantaquattro et al., 2005. Cinquantaquattro, T., Iodice, S.V., Guarino, A. Alta-media Valle del Clanis. In: Notiziario della Soprintendenza per i Beni Archeologici di Salerno, Avellino e Benevento, 1, pp. 23-26.

Coppola, G., 2015. Battaglie normanne di terra e di mare. Italia meridionale - secoli XI-XII. Liguori Ed: Napoli.

Coppola, G., Muollo, G. 1996, I castelli. In Storia illustrata di Avellino e dell'Irpinia, II, Pratola Serra, pp. 434-438.

Coppola, G., Muollo, G., 1994. Castelli medievali in Irpinia, Milano.

Cordella, F. 1997, A guardia del territorio. Torri, castelli e fortezze. Il castello di Avella. In: Campania Felix, 9, pp. 56-60.

El-Hakim, S., Gonzo, L., Voltolini, F., Girardi, S., Rizzi, A., Remondino, F., Whiting, E., 2007. Detailed 3D modeling of castles, in: International Journal of Architectural Computing, Vol. 5(2), pp. 199-220.
Erchemperto, 1995. Storia dei longobardi (sec. IX), Carucci, A. (ed.). Salerno-Roma.

Gallina, D., 2012. Sillogismo deduttivo o abduzione? Alcune proposte per l'abbandono/superamento del matrix di Harris nell'analisi dell'architettura. In: A. d. Giglio (ed.), VI Congresso Nazionale di Archeologia Medievale.

Harris, E. C., 2003. The stratigraphy of standing structures con alcune considerazioni in nota di R. Parenti. In: Archeologia dell'Architettura, VIII, pp. 9-16.

Iannelli, M.A. 1989, Per uno studio del castello di Avella: il contributo della ricerca archeologica. In: Carafa, R. (ed.), Il restauro dei castelli nell'Italia Meridionale, Caserta, pp. 159175.

Luhmann, T., Robson, S., Kyle, S., and Böhm J., 2014. Close Range Photogrammetry: $3 D$ Imaging Techniques $-2 \mathrm{nd}$ Edition. Walter De Gruyter Inc., Berlin, Germany.

Luhmann, T., Robson, S., Kyle, S., Harley, I., 2006. Close range photogrammetry: Principles, methods and applications, Whittles Publishing.

Parenti, R., 2009: Archeologia dell'architettura, Dizionario di Archeologia. Temi, concetti e metodi, pp. 39-43.

Peduto, P., 1984. Torri e castelli longobardi in Italia Meridionale: una nuova proposta. In Comba, R., Settia, A. (ed), Castelli storia e archeologia, Cuneo, pp. 391-399.

Pierrot-Deseilligny, M., De Luca, L., Remondino, F., 2011. Automated image-based procedures for accurate artifacts $3 D$ 
modeling and orthoimage generation, Proc. 23th Int. CIPA Symposium, Prague, Czech Republic.

PIT, 2003. Regione Campania, Comune di Avella (AV), Piano Territoriale Integrato. Valle dell'antico Clanis antica terra dei miti e degli dei. Il parco archeologico del castello di Avella. Progetto di consolidamento, restauro e valorizzazione.

Remondino F. \& El-Hakim S., 2006. Image-based 3D modelling: a review. In: The Photogrammetric Record, Vol. 21 (115), pp. 269-291.

Remondino F., 2011. Tecnologie per la comunicazione del patrimonio culturale. In: DISEGNARECON, december 2011.

Tumeliene E., Nareiko V., Suziedelyte Visockiene J., 2017. Photogrammetric measurements of heritage objects. In: ISPRS Annals of the Photogrammetry, Remote Sensing and Spatial Information Sciences, Volume IV-5/W1, Geospace 2017, 4-6 December 2017, Kyiv, Ukraine.

Yastikli N., Özerdema Ö. Z., 2017. Architectural heritage documentation by using low cost UAV with fisheye lens: Otag-i humayun in Istanbul as a case study. In: ISPRS Annals of the Photogrammetry, Remote Sensing and Spatial Information Sciences, Volume IV-4/W4, 2017 4th International GeoAdvances Workshop, 14-15 October 2017, Safranbolu, Karabuk, Turkey. 